\title{
Role of Stem Cells in Cardiac Diseases
}

Shibbani $\mathrm{K}^{1 \#}$, Hadadeh $\mathrm{O}^{2 \#}$, Bahmad $\mathrm{H}^{2}$, Abou-Kheir $\mathrm{W}^{2 *}$, Nemer $\mathrm{G}^{3^{*}}$

${ }^{1}$ Lieber Institute for Brain Development, Johns Hopkins, 855 N. Wolfe Street, Baltimore, MD, USA.

${ }^{2}$ Departments of Anatomy, Cell Biology, and Physiological Sciences, Lebanon.

${ }^{3}$ Biochemistry and Molecular Genetics, Faculty of Medicine, American University of Beirut, Beirut, Lebanon.

\# Authors contributed equally.

\section{Abstract}

Ischemic heart disease is the leading cause of global mortality, and cardiovascular diseases represent a major challenge for researchers because of the overall health complications associated with them. Numerous studies have shown that it is exceedingly difficult to induce cardiomyocytes to divide, resulting in a flood of interest in attempting to treat cardiac ischemia through the delivery of new cardiomyocytes. To do so, researchers have started investigating the potential of using induced pluripotent stem cells (iPS) to derive functional cardiomyocytes.

The diverse cells that compose the heart and the subdivision of cardiomyocytes make it difficult to generate specific cells with specific genetic and functional signatures. Hence, it is essential to define the cardiac progenitor cells' identity and subsequently design the best strategy to differentiate them into the appropriate mature functional cells.

Recent studies in animal models and some clinical trials have shown the beneficial effects of these iPS cells in decreasing morbidity and improving heart function. Yet, many hurdles still need to be overcome before generalizing the conclusions reached so far. These are related to the nature of the manipulated cells, their delivery into the host, and their interaction with the host cells. This review touches upon the current knowledge of Cardiac Progenitor Cells (CPC), the role of iPS cells in understanding cardiac disease, as well as the clinical trials and animal models involving stem cells and cardiac disease.

Keywords: iPS Cells; Cardiac Disease; Myocardial Infarction; Animal Models.

\section{Cardiac Progenitor Cells}

The heart is the first organ to become fully functional during development in all organisms. Despite numerous studies in model organisms in the last two decades, the identity of the cardiac progenitor cell (CPC) remains unclear. However, studies have confirmed that most cardiac cells originate from the mesoderm. Work in recent years has shed light on a few genetic markers that are believed to be candidates for expression on the illusive cardiac progenitor cell, such as NKX 2.5, ISL-1, FLK-1, MESP1 and others $[1-4]$.
In mouse embryonic development, cardiac progenitor cells (CPC) are believed to make their debut in a 24-hour window between days E6.5 and E7.5. Reports have indicated that the precursors for the heart forming cells must express MESP1. MESP1 expressing cells exist at day 6.5 in the primitive streak [5]. These cells, however, can give rise to non-cardiac lineages and thus MESP1 could be a marker of a progenitor cell that is upstream of the CPC [6].

As cells migrate away from the primitive streak and into the Anterior Lateral Plate Mesoderm, MESP1 expression drops and cardi-

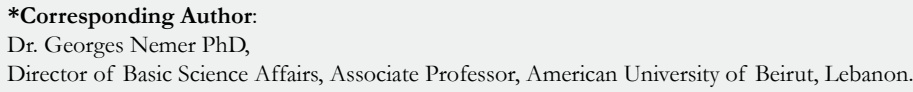

Copyright: Abou-Kheir W, Nemer $\mathbf{G}^{\circ}$ 2016. This is an open-access article distributed under the terms of the Creative Commons Attribution License, which permits unrestricted use, distribution and reproduction in any medium, provided the original author and source are credited. 
ac specific markers like NKX2.5 and ISL-1 begin to appear. These cells are now committed to making cardiac cells, mainly the future beating cardiomyocytes [7]. This ensues by day E7.5, and somewhere in between E6.5 and E7.5, a cardiac progenitor is born.

Recent work in human embryonic stem cells (hES) has identified a group of cells that are $\mathrm{KDR}^{+}$and are capable of producing all three cell-types needed to make the heart (cardiomyocytes, endodermal cells, and skeletal muscle cells). These cells represent the second wave of $\mathrm{FLK}^{+}$cells during embryonic development, the first giving rise to cells with a hemangioblast fate [8]. How close the second wave of $\mathrm{FLK}^{+}$cells is to the actual CPC is still not entirely clear, but equally exciting to the identification of these $\mathrm{FLK}^{+}$cells was the use of hES cells to do so. This serves as a proof of concept that stem cells can be used as an adequate platform to model human embryonic cardiac development and to interrogate the CPC riddle further.

The fact that we have not yet characterized the CPC has not discouraged the use of cardiac stem cells in the clinic. On the contrary, the lack of a defined CPC has led to a hodge-podge of clinical trials with different "cardiac stem cells" and conflicting results. The identification of a definitive CPC will solve a very intriguing scientific question, and will most certainly have tremendous ramifications on the applications of cardiac stem cells in the clinic.

\section{Cardiac Disease Modeling via Stem Cells}

Stem cells are an excellent tool to model cardiac diseases. Examples of cardiac diseases that have been studied through stem cell modeling include LEOPARD syndrome, biological pacing $[9,10]$ and long QT (LQT) syndrome [11, 12]. LEOPARD syndrome is an autosomal dominant developmental disorder, where the main disease phenotype is hypertrophic cardiomyopathy. In a study by Carvajal-Vergara et al., iPS cells were generated from a patient with a mutation in the PTPN11 gene, which encodes the SHP2 phosphatase. LEOPARD syndrome hiPS cells-derived cardio- myocytes are spontaneously hypertrophied in vitro and present a higher level of sarcomeric organization compared with hES cells or wild-type hiPS cells-derived cardiomyocytes. Therefore these characteristics are associated to a potential hypertrophic situation in patients [13]. LQT syndrome is a heritable disease correlated to prolongation of the QT interval on an electrocardiogram and could lead to a ventricular tachyarrhythmia which might cause an unexpected cardiac death [14]. Bellin et al. was able to generate iPS cells from two patients affected with LQT syndrome type 1, who have mutations in the KCNQ1 gene encoding the repolarizing potassium channel mediating the delayed rectifier I (Ks) current [15]. Noteworthy, cardiomyocytes derived from LQT syndrome type 1 patients exhibited extended action potentials compared with cells from control subjects and also had an increased sensitivity to catecholamine-induced tachyarrhythmia. This phenotype, which represents one of the most principal clinical features of these syndromes, was attenuated by beta-blockade. Thus, LQTs 1 patient-specific iPS cell-derived cardiomyocytes entirely replicated the disease phenotypes [16].

In these instances though, stem cells are being used more as a model of disease than as a treatment. Indeed, effective pacing devices may make the use of stem cells to treat arrhythmias merely an intellectual exercise, but it will certainly shed light on disease pathophysiology. Similarly, using stem cells to model cardiac abnormalities such as the long QT syndrome will provide valuable insight about disease pathophysiology as well as a great platform to test drugs safely (Figure 1).

\section{Stem cell use in cardiac Clinical Trials}

The appeal of using stem cells in cardiac disease is understandable. The heart has traditionally been viewed as a post-mitotic organ incapable of regenerating damaged tissue. Simultaneously, cardiac disease is the most frequent cause of death in the US, accounting for a $25 \%, 24.6 \%$ and $24.4 \%$ of all deaths in 2008,2009 , and 2010 respectively [17-19].

Figure 1. Schematic diagram of the potentials of human induced pluripotent stem (hiPS) cells in cardiovascular diseases. Skin fibroblasts are obtained from diseased patients, reprogrammed into iPS cells, and further differentiated into specific hiPS-derived cardiomyocytes. These differentiated cells can be utilized in 1 . Gene correction and regenerative medicine, 2.In-vitro models to decipher underlying mechanisms and pathophysiology of some cardiac disorders, and 3. Drug screening for new drugs discovery.

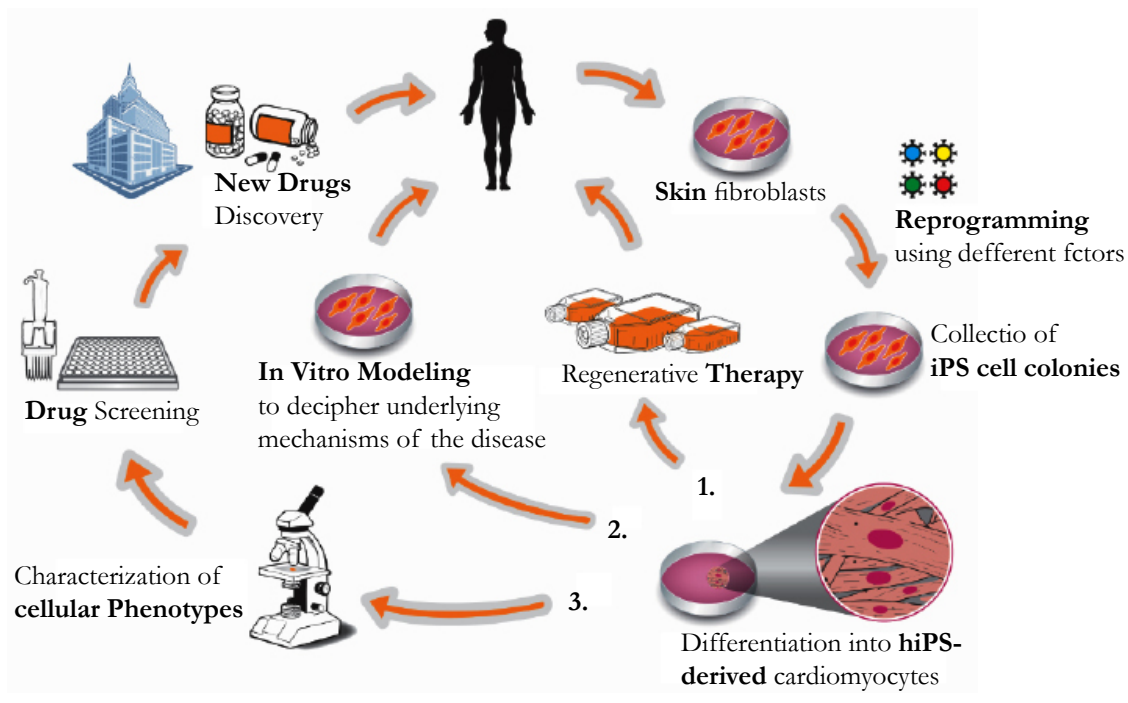


Subsequently, the use of stem cell therapies as part of cardiac disease treatment is gaining interest. A quick search on the NIH clinical trials database for the key words "stem cells" and "Heart" will yield upwards of 550 worldwide registered trials in various stages of progress with more than half of these trials taking place in the USA (www.clinicaltrials.gov). That being said, the vast majority of these trials are focused on treating myocardial ischemia and heart failure.

A review of some of the major clinical trials involving stem cells and heart disease is summarized in Table-1 and reveals some interesting findings. Paramount among those is the identification that the practice of stem cell injection into cardiac tissue is a safe one. One of the few findings that were reproduced in different

Table 1. Stem cell clinical trials in cardiac ischemia and heart failure.

\begin{tabular}{|c|c|c|c|c|c|c|c|}
\hline Trial & Patients & $\begin{array}{c}\text { Type of } \\
\text { Cell }\end{array}$ & \begin{tabular}{|l|} 
Source \\
of cells
\end{tabular} & Size of study & $\begin{array}{l}\text { Method of ad- } \\
\text { ministration }\end{array}$ & Endpoint & Outcome \\
\hline $\begin{array}{l}\text { Focus- } \\
\text { CCTRN } \\
{[21]}\end{array}$ & $\begin{array}{l}\text { Chronic is- } \\
\text { chemic heart } \\
\text { failure receiving } \\
\text { maximal medi- } \\
\text { cal therapy } \\
\end{array}$ & $\begin{array}{l}\text { Bone mar- } \\
\text { row mono- } \\
\text { nuclear } \\
\text { cells }\end{array}$ & $\begin{array}{l}\text { Bone } \\
\text { marrow }\end{array}$ & $\begin{array}{l}\cdot 61 \text { treated with } \\
\text { BMC } \\
\cdot 31 \text { control }\end{array}$ & $\begin{array}{l}\text { Transechocar- } \\
\text { dial injection } \\
\text { of BMC into } \\
\text { LV endocardial } \\
\text { regions }\end{array}$ & $\begin{array}{l}\text { Efficacy at } 6 \\
\text { months meas- } \\
\text { ured by LVESV, } \\
\text { maximal oxygen } \\
\text { consumption }\end{array}$ & $\begin{array}{l}\text { The treatment was not efficacious. No significant } \\
\text { changes were detected between patients treated with } \\
\text { BMC or control }\end{array}$ \\
\hline $\begin{array}{l}\text { CADU- } \\
\text { CEUS } \\
{[22]}\end{array}$ & $\begin{array}{l}\text { Ischemic heart } \\
\text { disease patients } \\
\text { 2-4 weeks post } \\
\text { MI }\end{array}$ & $\begin{array}{l}\text { Card- } \\
\text { ishphere } \\
\text { derived } \\
\text { autologous } \\
\text { stem cell }\end{array}$ & $\begin{array}{l}\text { Endo- } \\
\text { myo- } \\
\text { cardial } \\
\text { Biopsy }\end{array}$ & $\begin{array}{l}\cdot 17 \text { treated with } \\
\text { CDC } \\
\cdot 8 \text { Control }\end{array}$ & $\begin{array}{l}\text { Catheter infu- } \\
\text { sion of cells } \\
\text { into infarct } \\
\text { related artery }\end{array}$ & $\begin{array}{l}\cdot \text { Safety } \\
\text { Efficacy }\end{array}$ & $\begin{array}{l}\text { - Safety: } 1 \text { incidence of Q-wave MI in } 1 \text { patient was } \\
\text { regarded as related or likely related to the study } \\
\text { - Efficacy at } 6 \text { mnths: Reduction in scar size - in- } \\
\text { crease viable heart mass - increase regional contrac- } \\
\text { tility - increase systolic wall thickening. No change in } \\
\text { End Diastolic Volume - No change in End Systolic } \\
\text { Volume - No difference in LVEF with control }\end{array}$ \\
\hline $\begin{array}{l}\text { SCIPIO } \\
{[23]}\end{array}$ & $\begin{array}{l}\text { Ischemic heart } \\
\text { disease patients } \\
113 \text { days post } \\
\text { CABG }\end{array}$ & $\begin{array}{l}\text { c-kit }(+) \\
\text { lineage }(-) \\
\text { cardiac } \\
\text { stem cells }\end{array}$ & $\begin{array}{l}\text { Atrial } \\
\text { biopsy }\end{array}$ & $\begin{array}{l}\cdot 16 \text { treated with } \\
\text { CSC } \\
\cdot 7 \text { control }\end{array}$ & $\begin{array}{l}\text { Catheter infu- } \\
\text { sion of cells } \\
\text { into infarct } \\
\text { related artery }\end{array}$ & $\begin{array}{l}\cdot \text { Safety } \\
\cdot \text { Efficacy }\end{array}$ & $\begin{array}{l}\text { - Safety: no association with adverse effects for up } \\
\text { to } 1 \text { year } \\
\text { - Efficacy: Reduction in scar size - increase in LVEF } \\
\text { - Decrease in NYHA score - increase in MLHFQ } \\
\text { score }\end{array}$ \\
\hline $\begin{array}{l}\text { POSEI- } \\
\text { DON } \\
{[24]}\end{array}$ & $\begin{array}{l}\text { Patients with } \\
\text { chronic LV } \\
\text { dysfunction } \\
\text { due to ischemic } \\
\text { injury }\end{array}$ & $\begin{array}{l}\text { Mesanchy- } \\
\text { mal stem } \\
\text { cell }\end{array}$ & \begin{tabular}{|l|} 
Iliac \\
crest \\
bone \\
marrow \\
aspirate
\end{tabular} & $\begin{array}{l}31 \text { patients } \\
\text { treated with } \\
\text { different dose } \\
\text { of MSC from } \\
\text { allogenic and } \\
\text { autologous } \\
\text { sources }\end{array}$ & $\begin{array}{l}\text { Transendocar- } \\
\text { dial injection } \\
\text { into infarcted } \\
\text { myocardium }\end{array}$ & $\begin{array}{l}\text { Safety: serious } \\
\text { and non serious } \\
\text { adverse events } \\
\text { - Efficacy: } \\
\text { NYHA class } \\
- \text { O2 consump- } \\
\text { tion - walk test } \\
\text { - MLFHQ } \\
\end{array}$ & $\begin{array}{l}\text { Safety: } 6.7 \% \text { presence of SAE at } 30 \text { days. } 33 \% \text { and } \\
53.3 \% \text { presence of SAE in allogenic and autologous } \\
\text { group at } 1 \text { year respectively. } \\
\text { - Efficacy: autologous MSC associated with } 6 \text { min } \\
\text { walk test and MLHFQ - Allogenic MSC reduced } \\
\text { LVED volume - Allogenic and autologous MSC } \\
\text { reduced mean EED and spherecity index }\end{array}$ \\
\hline $\begin{array}{l}\text { SWISS- } \\
\text { AMI } \\
{[25]}\end{array}$ & $\begin{array}{l}\text { Acute ST eleva- } \\
\text { tion myocardial } \\
\text { infarction with } \\
\text { SPCI }\end{array}$ & $\begin{array}{l}\text { Bone mar- } \\
\text { row mono- } \\
\text { nuclear } \\
\text { cells }\end{array}$ & $\begin{array}{l}\text { iliac } \\
\text { crest } \\
\text { bone } \\
\text { marrow } \\
\text { aspirate }\end{array}$ & $\begin{array}{l}\cdot 65 \text { early } \\
\text { BMNC treat- } \\
\text { ment } \\
\cdot 63 \text { late BMNC } \\
\text { treatment } \\
\cdot 67 \text { control }\end{array}$ & $\begin{array}{l}\text { Intracoronary } \\
\text { infusion into } \\
\text { previously in- } \\
\text { farcted vessel } \\
\text { within } 5-7 \text { days } \\
\text { (early) or 3-4 } \\
\text { weeks (late) } \\
\end{array}$ & $\begin{array}{l}\cdot \text { Change in } \\
\text { LVEF at } 4 \\
\text { months }\end{array}$ & $\begin{array}{l}\text { - No difference between control group, early group, } \\
\text { or late group in } 4 \text { month LVEF }\end{array}$ \\
\hline $\begin{array}{l}\text { TIME } \\
{[26]}\end{array}$ & $\begin{array}{l}\text { Acute Myocar- } \\
\text { dial infarction } \\
\text { with successful } \\
\text { reperfusion }\end{array}$ & $\begin{array}{l}\text { Bone mar- } \\
\text { row mono- } \\
\text { nuclear } \\
\text { cells }\end{array}$ & $\begin{array}{l}\text { Bone } \\
\text { marrow } \\
\text { aspirate }\end{array}$ & $\begin{array}{l}\cdot 79 \text { treatment } \\
\cdot 41 \text { placebo }\end{array}$ & $\begin{array}{l}\text { Intracoronary } \\
\text { infusion into } \\
\text { previously in- } \\
\text { farcted vessel at } \\
3 \text { days vs } 7 \text { days }\end{array}$ & $\begin{array}{l}\text { Efficacy } \\
\text { at } 6 \text { months } \\
\text { measured by } \\
\text { LVEF and LV } \\
\text { wall motion } \\
\text { Safety: Major } \\
\text { adverse cardiac } \\
\text { events }\end{array}$ & $\begin{array}{l}\text { - Safety: No major adverse effect in the treatment } \\
\text { group } \\
\text { - Efficacy: The treatment had no significant effect on } \\
\text { LVEF or wall motion between groups treated at } 3 \\
\text { days, } 7 \text { days, or control groups }\end{array}$ \\
\hline $\begin{array}{l}\text { Late } \\
\text { TIME } \\
{[27]}\end{array}$ & $\begin{array}{l}\text { Acute Myocar- } \\
\text { dial infarction } \\
\text { with successful } \\
\text { reperfusion }\end{array}$ & $\begin{array}{l}\text { Bone mar- } \\
\text { row mono- } \\
\text { nuclear } \\
\text { cells }\end{array}$ & \begin{tabular}{|l|} 
Iliac \\
crest \\
bone \\
marrow \\
aspirate \\
\end{tabular} & $\begin{array}{l}\cdot 58 \text { treatment } \\
\cdot 29 \text { placebo }\end{array}$ & $\begin{array}{l}\text { Intracoronary } \\
\text { infusion of } \\
\text { BMC at } 2-3 \\
\text { weeks post MI }\end{array}$ & $\begin{array}{l}\text { Efficacy at } 6 \\
\text { months meas- } \\
\text { ured by LVEF } \\
\text { and LV wall } \\
\text { motion } \\
\end{array}$ & $\begin{array}{l}\text { The treatment had no significant effect on LVEF } \\
\text { or wall motion between groups treated at } 2-3 \text { weeks } \\
\text { or control groups }\end{array}$ \\
\hline $\begin{array}{l}\text { C-CURE } \\
{[28]}\end{array}$ & $\begin{array}{l}\text { Chronic heart } \\
\text { failure of is- } \\
\text { chemic origin }\end{array}$ & $\begin{array}{l}\text { Cardio- } \\
\text { peitc stem } \\
\text { cell }\end{array}$ & $\begin{array}{l}\text { Iliac } \\
\text { crest } \\
\text { bone } \\
\text { marrow } \\
\text { aspirate }\end{array}$ & $\begin{array}{l}\cdot 20 \text { treatment } \\
\cdot 13 \text { placebo }\end{array}$ & $\begin{array}{l}\text { Endoventricular } \\
\text { injection of } \\
\text { cells }\end{array}$ & $\begin{array}{l}\cdot \text { Safety and } \\
\text { feasibility } \\
\cdot \text { Efficacy of } \\
\text { treatment }\end{array}$ & $\begin{array}{l}\text { - Safety: No evidence of cardiac or sys- } \\
\text { temic toxicity identified by study } \\
\text { Feasibility: In } 75 \% \text { of patients who underwent bi- } \\
\text { opsy, adequate stem cells were produced and injected } \\
\text { back into the heart } \\
\text { - Efficacy: Improved LVEF, decreased LVES vol- } \\
\text { ume, improved } 6 \text { min walk distance, improved qual- } \\
\text { ity of life scores }\end{array}$ \\
\hline $\begin{array}{l}\text { MAGIC } \\
{[29]}\end{array}$ & $\begin{array}{l}\text { Patients with } \\
\text { ischemic left } \\
\text { ventricular dys- } \\
\text { function requir- } \\
\text { ing CABG } \\
\text { surgery } \\
\end{array}$ & $\begin{array}{l}\text { Skel- } \\
\text { etal muscle } \\
\text { myoblast }\end{array}$ & $\begin{array}{l}\text { Muscle } \\
\text { biopsy } \\
\text { from } \\
\text { the } \\
\text { thigh }\end{array}$ & $\begin{array}{l}67 \text { treated with } \\
\text { skeletal muscle } \\
\text { myoblast at } 2 \\
\text { different doses } \\
\cdot 30 \text { control }\end{array}$ & $\begin{array}{l}\text { Multiple site in- } \\
\text { jection of cells } \\
\text { into a kinetic } \\
\text { myocardium }\end{array}$ & $\begin{array}{l}\cdot \text { Safety: Pres- } \\
\text { ence Major } \\
\text { cardiac events } \\
\cdot \text { Efficacy: } \\
\text { Global or LV } \\
\text { function change }\end{array}$ & $\begin{array}{l}\text { - Safety: No major adverse cardiac events resulted } \\
\text { from treatment } \\
\text { - Efficacy: No difference in LV function between } \\
\text { patients who received skeletal muscle myoblast or } \\
\text { placebo }\end{array}$ \\
\hline
\end{tabular}

BMC: Bone Marrow Mononuclear Cells. LV: Left Ventricle. LVESV: Left Ventricular End Systolic Volume. MI: Myocardial Infarction. CDC: Cardioshpere Derived Cells. LVEF: Left Ventricular Ejection Fraction. CABG: Coronary Artery Bypass Graft. CSC: Cardiac Stem Cell. NYHA: New York Heart Association. MLHFQ: Minnesota Living With Heart Failure Questionnaire. MSC: Mesenchymal Stem Cells. EED: Early Enhancement Defect. BMNC: Blood Mono Nuclear Cells. SPCI: Successful Percutaneous Intervention. BMC: Bone Marrow Mono Nuclear Cells. 
trials was the safety of stem cell treatments. Indeed, there seems to be minimal to no adverse outcomes from administration of stem cells into the heart. Some of the concerns had previously included the differentiation of the stem cells into cancerous cells within the heart, as well as the interruption of the highly regulated cardiac conduction system and the subsequent development of arrhythmias, among others - all of which are apparently not a major concern when using stem cells to treat cardiac disease.

Another important take away from the various trials is the feasibility of such a treatment. The idea of culturing stem cells from the body (and in some instances creating iPS cells), expanding them, and injecting them back into the heart may have seemed like stuff of science fiction a few decades ago. The abundance of clinical trials doing just that, and with efficiency, is proof of the feasibility of such procedures.

It's not all-good news though. Some of the limitations of the trials include a short follow up period that ranged from 4 months to 1 year, conflicting outcomes, and a lack of a clear understanding what is happening at the molecular and biological level. As far as follow up time goes, a longer follow up period of up to 5 years will surely be more informative in terms of efficacy and safety, and future trials will likely tackle this point. The more important limitation, however, is the contradictory results reported by the trials. The lack of standardization between the trials with regards to the type of stem cells used for treatment, patient population, timing, dose, end points, and many other variables resulted in clinical trials that are not easily comparable to one another and often yielding contradictory results. What is not contradic-

Table 2. iPS cell use in animal models of cardiac disease.

\begin{tabular}{|c|c|c|c|c|}
\hline Disease model & Animal Used & Stem cell used & Endpoint & Result \\
\hline MI [30] & Rat & $\begin{array}{l}\text { MSC / BCL-2 engi- } \\
\text { neered }\end{array}$ & $\begin{array}{l}\text { - Revascularization } \\
\text { - Cell survival } \\
\text { - Functional improvement in LV at } 6 \text { weeks }\end{array}$ & $\begin{array}{l}\cdot \text { Decreased apoptosis } \\
\cdot \text { Increased survival } \\
\cdot \text { Smaller infarct size } \\
\cdot \text { Improvement in LV function }\end{array}$ \\
\hline MI [31] & Rat & MSC & $\begin{array}{l}\text { - Infarct size } \\
\text { - Functional improvement in LV at } 6 \text { weeks }\end{array}$ & $\begin{array}{l}\text { - No impairment in LV function } \\
\text { - Abnormal colonies detected }\end{array}$ \\
\hline MI [20] & Mouse & ESC & $\begin{array}{l}\text { - Fate of ES cells injected into heart } \\
\text { - Effect of ES cell injection on cardiac size } \\
\text { and function }\end{array}$ & $\begin{array}{l}\text { - ES cells became cardiomyocytes } \\
\text { - Reduced cardiac modeling } \\
\text { - Improved cardiac function }\end{array}$ \\
\hline MI [32] & Mouse & iPS & $\begin{array}{l}\text { - Effect of iPS cell injection on cardiac } \\
\text { function }\end{array}$ & $\begin{array}{l}\text { - Improved cardiac function } \\
\text { - Decreased remodeling }\end{array}$ \\
\hline MI [33] & Mouse & BM vs. UCB & $\begin{array}{l}\text { - Cardiac function and histological assess- } \\
\text { ment }\end{array}$ & $\begin{array}{l}\cdot \text { Scar size was same in } \mathrm{BM}, \mathrm{UCB} \\
\text { and Control } \\
\cdot \text { Decreased apoptosis in } \mathrm{BM} \text { and } \\
\mathrm{UCB} \\
\cdot \text { Only BM improved contractility }\end{array}$ \\
\hline MI [34] & Mouse & hUCB & $\begin{array}{l}\text { - Effect of cells on cardiac repair follow- } \\
\text { ing MI }\end{array}$ & $\begin{array}{l}\text { hUCB migrated to infarcted } \\
\text { region and aided in remodeling }\end{array}$ \\
\hline MI [35] & Rat & BM-MNC & - Safety and therapeutic effectiveness & $\begin{array}{l}\text { - Increased neovascularization } \\
\text { Increased EF }\end{array}$ \\
\hline $\mathrm{HF}[36]$ & Sheep & $\mathrm{UCMNC}$ & $\begin{array}{l}\text { - Cardiac function and histological assess- } \\
\text { ment }\end{array}$ & $\begin{array}{l}\text { - Enhanced RV diastolic function } \\
\text { - Increased angiogenesis }\end{array}$ \\
\hline $\mathrm{HF}[37]$ & Rabbit & BMC & - Contractility and capillary density & $\begin{array}{l}\text { Increased contractility in treated } \\
\text { hearts } \\
\cdot \text { Increased vascularization in } \\
\text { treated hearts }\end{array}$ \\
\hline MI [38] & Rabbit & BM-MSC & - Assess cardiac function & $\begin{array}{l}\cdot \text { Markedly improved cardiac } \\
\text { function } \\
\cdot \text { Decrease area of fibrosis } \\
\cdot \text { Increase number of capillaries } \\
\end{array}$ \\
\hline MI [39] & Dog & $\mathrm{CSC}$ & $\begin{array}{l}\text { Assess effect of resident CSC on infarcted } \\
\text { heart }\end{array}$ & $\begin{array}{l}\text { - Marked recovery in contrac- } \\
\text { tile function Vascularization of } \\
\text { scarred tissue }\end{array}$ \\
\hline $\mathrm{HF}[40]$ & Dog & MSC & - Contractility and histopathological change & $\begin{array}{l}\text { Improved EF in treated dogs } \\
\text { after } 60 \text { days } \\
\text { Increased vascularization }\end{array}$ \\
\hline MI [41] & Sheep & MPC & - Dose dependent effect on LV post MI & $\begin{array}{l}\cdot \text { Low dose increased LVEDV and } \\
\text { LVESV } \\
\cdot \text { Lower doses increased vascular } \\
\text { density at border zone } \\
\cdot \text { All doses increased EF }\end{array}$ \\
\hline MI [35] & Pig & BM-MNC & $\begin{array}{l}\text { Therapeutic effectiveness of BM-MNC } \\
\text { injection }\end{array}$ & $\begin{array}{l}\text { - Improved cardiac function } \\
\text { - Increased capillary density at } \\
\text { scar site } \\
\text { - Increased regional blood flow } \\
\end{array}$ \\
\hline MI [42] & Pig & EPC & $\begin{array}{l}\text { - Post MI effect of EPC and EPC condi- } \\
\text { tioned media injection }\end{array}$ & $\begin{array}{l}\text { Increased ventricular func- } \\
\text { tion and cardiomyocyte size at } 2 \\
\text { months in both groups }\end{array}$ \\
\hline MI [43] & Pig & MSC & - Effect of MSC on cardiac nerve density & $\cdot$ Increased cardiac nerve sprouting \\
\hline
\end{tabular}

MI: Myocardial Infarction. MSC: Mesenchymal Stem Cell. LV: Left Ventricle. ESC: Embryonic Stem Cell. iPS: induced Pluripotent Stem Cell. BM: Bone Marrow. UCB: Umbilical Cord Blood. hUCB: Human Umbilical Cord Blood. BM-MNC: Bone Marrow Mono Nuclear Cell. EF: Ejection Fraction. HF: Heart Failure. UC-MNC: Umbilical Cord Mono Nuclear Cells. RV: Right Ventricle. BMC: Bone Marrow derived Stem Cells. CPC: Cardiac Progenitor Cells. MPC: Mesenchymal Precursor Cells. EPC: Endothelial Progenitor Cells. ADSC: Adipocyte Derived Stem Cell 
tory, however, is that these conflicting results cast a shadow of doubt on any favorable results that the trials have reported. And more importantly, they emphasize the necessity of conducting a standardized trial with clear endpoints and parameters and a large patient population to yield powerful results that will provide an unequivocal answer to the question of efficacy of stem cell treatment in cardiac disease.

Animal models that studied the efficacy of stem cell treatment in cardiac disease have reported that the stem cells injected into the heart are mostly not differentiating into cardiomyocytes in vivo. Rather, improvement in cardiac function were shown to be due to a paracrine effect exerted by these stem cells as well as an increase in the neovascularization of scared tissues, though exactly how and what is happening is still unclear. Human trials have so far not addressed this issue clearly. Thereby, understanding the molecular effects of stem cells in cardiac disease will help design better clinical trials in the future by elucidating the best type of cells to use, as well as the timing and location of stem cell injection.

\section{Animal models}

Mice, rodents, sheep, rabbits, dogs, and pigs have been used to interrogate the efficacy of using stem cells in the treating cardiac disease. Though the endpoints varied wildly, the results were consistent in different animal models across the board, as summarized in Table-2. Unlike human trials, animal models show a clear benefit in using stem cells to treat chronic heart failure and acute myocardial infarctions. This result has been repeated in almost all the species used to model the disease. Neovascularization is the most commonly identified culprit in recovery, and it was detected in most of the trials. While most trials claimed that the enhanced cardiac function was also partly due to a paracrine effect, a few trials identified the generation of new cardiomyocytes in the heart. One such exception is the Singla et al. study [20], where the injection of embryonic stem cells into a mouse heart after an MI resulted in all three cardiac cell types of the heart. While this result is quite encouraging, it faces a major obstacle in human application - namely the use of human embryonic stem cells in research.

\section{Conclusion}

Stem cell use especially iPS cells in cardiac disease holds great promise for the future. And while many trials have produced encouraging results, there needs to be a well-conducted study that can tackle the shortcomings of present trials and follow a standardized protocol that will lend greater credibility to the results that such a trial will produce.

\section{References}

[1]. Scott IC, Benoit GB (2012) Life before Nkx2.5: Cardiovascular Progenitor Cells: Embryonic Origins and Development. Curr Top Dev Biol 100: 1-31.

[2]. Barnett P, van den Boogaard M, Christoffels V (2012) Localized and Temporal Gene Regulation in Heart Development. Curr Top Dev Biol 100: 171-201.

[3]. Lindsley RC, Gill JG, Murphy TL, Langer EM, Cai M (2008) Mesp1 Coordinately Regulates Cardiovascular Fate Restriction and Epithelial-Mesenchymal Transition in Differentiating ESCs. Cell Stem Cell 3(1): 55-68.

[4]. Chan SS, Shi X, Toyama A, Arpke RW, Dandapat A (2013) Mesp1 patterns mesoderm into cardiac, hematopoietic, or skeletal myogenic progenitors in a context-dependent manner. Cell Stem Cell 12(5): 587-601.

[5]. Solloway MJ, Harvey RP (2003) Molecular pathways in myocardial devel- opment: a stem cell perspective. Cardiovasc Res 58(2): 264-277.

[6]. Saga Y, Miyagawa-Tomita S, Takagi A, Kitajima S, Miyazaki Ji, et al. (1999) MesP1 is expressed in the heart precursor cells and required for the formation of a single heart tube. Development 126(15): 3437-3447.

[7]. Wu SM, Chien KR, Mummery C (2008) Origins and Fates of Cardiovascular Progenitor Cells. Cell 132(4): 537-543.

[8]. Yang L, Soonpaa MH, Adler ED, Roepke TK, Kattman SJ, et al. (2008) Human cardiovascular progenitor cells develop from a KDR+ embryonicstem-cell-derived population. Nature 453(7194): 524-528.

[9]. Rosen MR, Brink PR, Cohen IS, Robinson RB (2004) Genes, stem cells and biological pacemakers. Cardiovasc Res 64(1): 12-23.

[10]. Rosen MR (2014) Gene Therapy and Biological Pacing. N Engl J Med 371(12): 1158-1159.

[11]. Fatima A, Kaifeng S, Dittmann S, Xu G, Gupta MK, et al. (2013) The Disease-Specific Phenotype in Cardiomyocytes Derived from Induced Pluripotent Stem Cells of Two Long QT Syndrome Type 3 Patients. PLoS ONE 8(12): e83005.

[12]. Li G, Cheng G, Wu J, Ma S, Sun C (2014) New iPSC for old long QT syndrome modeling: Putting the evidence into perspective. Exp Biol Med 239(2): 131-140.

[13]. Carvajal-Vergara X, Sevilla A, D'Souza SL, Ang YS, Schaniel C, et al. (2010) Patient-specific induced pluripotent stem-cell-derived models of LEOPARD syndrome. Nature 465(7299): 808-812.

[14]. Müller M, Seufferlein T, Illing A, Homann J (2013) Modelling Human Channelopathies Using Induced Pluripotent Stem Cells: A Comprehensive Review. Stem Cells International 2013: 1-7.

[15]. Bellin M, Marchetto MC, Gage FH, Mummery CL, et al. (2012) Induced pluripotent stem cells: the new patient? Nat Rev Mol Cell Biol 13(11): 713726.

[16]. Sallam K, Kodo K, Wu JC (2014) Modeling Inherited Cardiac Disorders. Circ J 78(4): 784-794.

[17]. Minino AM, Xu J, Kochanek KD (2010) Deaths: preliminary data for 2008. Natl Vital Stat Rep 59(2): 1-52.

[18]. Kochanek KD, Xu J, Murphy SL, Miniño AM, Kung HC (2011) Deaths: final data for 2009. Natl Vital Stat Rep 60(3): 1-116.

[19]. Murphy SL, Xu J, Kochanek KD (2013) Deaths: final data for 2010. Natl Vital Stat Rep 61(4): 1-118.

[20]. Singla DK, Hacker TA, Ma L, Douglas PS, Sullivan R, et al. (2006) Transplantation of embryonic stem cells into the infarcted mouse heart: formation of multiple cell types. J Mol Cell Cardiol 40(1): 195-200.

[21]. Perin EC, Willerson JT, Pepine CJ, Henry TD, Ellis SG, et al. (2012) Effect of Transendocardial Delivery of Autologous Bone Marrow Mononuclear Cells on Functional Capacity, Left Ventricular Function, and Perfusion in Chronic Ischemic Heart Failure: The FOCUS-CCTRN Trial. JAMA 307(16): 1717-1726.

[22]. Makkar RR, Smith RR, Cheng K, Malliaras K, Thomson LE, et al. (2012) Intracoronary cardiosphere-derived cells for heart regeneration after myocardial infarction (CADUCEUS): a prospective, randomised phase 1 trial. Lancet 379(9819): 895-904.

[23]. Bolli R, Chugh AR, D'Amario D, Loughran JH, Stoddard MF, et al. (2011) Effect of Cardiac Stem Cells in Patients with Ischemic Cardiomyopathy: Initial Results of the SCIPIO Trial. Lancet 378(9806): 1847-1857.

[24]. Hare JM, Fishman JE, Gerstenblith G, DiFede Velazquez DL, Zambrano JP, et al. (2012) Comparison of allogeneic vs autologous bone marrow-derived mesenchymal stem cells delivered by transendocardial injection in patients with ischemic cardiomyopathy: the POSEIDON randomized trial. JAMA 308(22): 2369-2379.

[25]. Sürder D, Manka R, Lo Cicero V, Moccetti T, Rufibach K, et al. (2013) Intracoronary injection of bone marrow-derived mononuclear cells early or late after acute myocardial infarction: effects on global left ventricular function. Circulation 127(19): 1968-1979.

[26]. Traverse JH, Henry TD, Pepine CJ, Willerson JT, Zhao DX, et al. (2012) Effect of the Use and Timing of Bone Marrow Mononuclear Cell Delivery on Left Ventricular Function After Acute Myocardial Infarction: The TIME Randomized Trial. JAMA 308(22): 2380-2389.

[27]. Traverse JH, Henry TD, Vaughan DE, Ellis SG, Pepine CJ, et al. (2010) LateTIME: A Phase-II, Randomized, Double-Blinded, Placebo-Controlled, Pilot Trial Evaluating the Safety and Effect of Administration of Bone Marrow Mononuclear Cells 2 to 3 Weeks after Acute Myocardial Infarction. Tex Heart Inst J 37(4): 412-420.

[28]. Bartunek J, Behfar A, Dolatabadi D, Vanderheyden M, Ostojic M, et al. (2013) Cardiopoietic Stem Cell Therapy in Heart Failure: The C-CURE (Cardiopoietic stem Cell therapy in heart failURE) Multicenter Randomized Trial With Lineage-Specified Biologics. J Am Coll Cardiol 61(23): 2329-2338.

[29]. Menasché P, Alfieri O, Janssens S, McKenna W, Reichenspurner H, et al. (2008) The Myoblast Autologous Grafting in Ischemic Cardiomyopathy 
(MAGIC) Trial: First Randomized Placebo-Controlled Study of Myoblast Transplantation. Circulation 117(9): 1189-1200.

[30]. Li W, Ma N, Ong LL, Nesselmann C, Klopsch C, et al. (2007) Bcl-2 Engineered MSCs Inhibited Apoptosis and Improved Heart Function. Stem Cells 25(8): 2118-2127.

[31]. Furlani D, Li W, Pittermann E, Klopsch C, Wang L, et al. (2009) A Transformed Cell Population Derived From Cultured Mesenchymal Stem Cells Has no Functional Effect After Transplantation Into the Injured Heart. Cell Transplant 18(3): 319-331.

[32]. Nelson TJ, Martinez-Fernandez A, Yamada S, Perez-Terzic C, Ikeda Y, et al. (2009) Repair of Acute Myocardial Infarction by Human Stemness Factors Induced Pluripotent Stem Cells. Circulation 120(5): 408-416.

[33]. Ma N, Ladilov Y, Moebius JM, Ong L, Piechaczek C, et al. (2006) Intramyocardial delivery of human CD133+ cells in a SCID mouse cryoinjury model: Bone marrow vs. cord blood-derived cells. Cardiovasc Res 71(1): 158-169.

[34]. Ma N, Stamm C, Kaminski A, Li W, Kleine HD, et al, (2005) Human cord blood cells induce angiogenesis following myocardial infarction in NOD/ scid-mice. Cardiovasc Res 66(1): 45-54

[35]. Kamihata H, Matsubara H, Nishiue T, Fujiyama S, Tsutsumi Y, et al. (2001) Implantation of Bone Marrow Mononuclear Cells Into Ischemic Myocardium Enhances Collateral Perfusion and Regional Function via Side Supply of Angioblasts, Angiogenic Ligands, and Cytokines. Circulation 104(9): 1046-1052.

[36]. Yerebakan C, Sandica E, Prietz S, Klopsch C, Ugurlucan M, et al. (2009) Autologous Umbilical Cord Blood Mononuclear Cell Transplantation Preserves Right Ventricular Function in a Novel Model of Chronic Right Ventricular Volume Overload. Cell Transplant 18(8): 855-868.

[37]. Garbade J, Dhein S, Lipinski C, Aupperle H, Arsalan M, et al. (2009) Bone Marrow-Derived Stem Cells Attenuate Impaired Contractility and En- hance Capillary Density in a Rabbit Model of Doxorubicin-Induced Failing Hearts. J Card Surg 24(5): 591-599.

38]. Xu YL, Gao YH, Liu Z, Tan KB, Hua X, et al. (2010) Myocardium-targeted transplantation of mesenchymal stem cells by diagnostic ultrasound-mediated microbubble destruction improves cardiac function in myocardial infarction of New Zealand rabbits. Int J Cardiol 138(2): 182-195.

[39]. Linke A, Müller P, Nurzynska D, Casarsa C, Torella D, et al. (2005) Stem cells in the dog heart are self-renewing, clonogenic, and multipotent and regenerate infarcted myocardium, improving cardiac function. Proc Natl Acad Sci U S A 102(25): 8966-8971.

[40]. Silva GV, Litovsky S, Assad JA, Sousa AL, Martin BJ, et al. (2005) Mesenchymal Stem Cells Differentiate into an Endothelial Phenotype, Enhance Vascular Density, and Improve Heart Function in a Canine Chronic Ischemia Model. Circulation 111(2): 150-156.

[41]. Hamamoto H, Gorman JH 3rd, Ryan LP, Hinmon R, Martens TP, et al. (2009) Allogeneic Mesenchymal Precursor Cell Therapy to Limit Remodeling After Myocardial Infarction: The Effect of Cell Dosage. Ann Thorac Surg 87(3): 794-801.

[42]. Doyle B, Sorajja P, Hynes B, Kumar AH, Araoz PA, et al. (2008) Progenitor Cell Therapy in a Porcine Acute Myocardial Infarction Model Induces Cardiac Hypertrophy, Mediated by Paracrine Secretion of Cardiotrophic Factors Including TGFbeta1. Stem Cells Dev 17(5): 941-951.

[43]. Pak HN, Qayyum M, Kim DT, Hamabe A, Miyauchi Y, et al. (2003) Mesenchymal Stem Cell Injection Induces Cardiac Nerve Sprouting and Increased Tenascin Expression in a Swine Model of Myocardial Infarction. J Cardiovasc Electrophysiol 14(8): 841-848. 